\title{
Performance and carcass characteristics of lambs fed a solution of crude glycerin during feedlot and pre-slaughter lairage
}

\author{
Fredson Vieira e Silva ${ }^{1 *}$, Iran Borges ${ }^{2}$, Vandenberg Lira Silva ${ }^{2}$, Ângela Maria Quintão Lana ${ }^{2}$, \\ Ana Luiza Costa Cruz Borges², Sidnei Tavares dos Reis ${ }^{1}$, Alexandre Ribeiro Araújo², Aylle \\ Medeiros Matos ${ }^{1}$
}

\author{
${ }^{1}$ Universidade Estadual de Montes Claros, Departamento de Ciências Agrárias, Janaúba, MG, Brasil. \\ 2 Universidade Federal de Minas Gerais, Escola de Veterinária, Departamento de Zootecnia, Belo Horizonte, MG, Brasil.
}

\begin{abstract}
The objective of this study was to evaluate performance and carcass and meat characteristics of lambs fed a solution of crude glycerin plus water (100 g kg-1 of dry matter) (GLY) during feedlot and pre-slaughter lairage. Data were analyzed as a $2 \times 2$ factorial (GLY available or not in feedlot and GLY available or not in the slaughterhouse). We evaluated the following treatments (feedlot/slaughterhouse): GLY/GLY, GLY/water, water/GLY, and water/water (control). Lambs fed a balanced diet for 70 days in the feedlot. Slaughter started $12 \mathrm{~h}$ after the animals arrived at the slaughterhouse. Dry matter intake, feed conversion, average daily gain, and body weight of lambs fed GLY were similar to those of control lambs. Lambs receiving GLY ingested more water in the feedlot. At the slaughterhouse, water/GLY animals ingested more glycerin and water than GLY/water animals ingested water. Group GLY/GLY had lower drip loss in carcasses than the group GLY/water. The other carcass and meat characteristics (carcass weight, $\mathrm{pH}$, subcutaneous fat thickness, ribeye area, color, water holding capacity, cooking losses, and shear force) were similar among treatments. Solution of crude glycerin plus water can be used as a dietary ingredient for lambs, since it improves hydration and does not change performance and carcass characteristics. This solution supplied as a pre-slaughter supplement does not improve carcass and meat characteristics.
\end{abstract}

Key Words: carcass quality, meat quality, sheep, slaughterhouse, welfare

\section{Introduction}

The global concern with energy resources drives the search for possible fuel substitutes for oil. Several potential renewable energy sources, such as bioethanol and biodiesel, have arisen. The latter has shown significant growth in popularity in Brazil due to government incentives that established the addition of a minimum of $70 \mathrm{~g} \mathrm{~kg}^{-1}$ biodiesel in commercial diesel (Brasil, 2014). Given the increased amount of biodiesel production, there is a greater production of its byproduct, glycerin.

Glycerin, a colorless, viscous, odorless, hygroscopic, sweet-tasting liquid, is a sugar alcohol with a high water solubility index (Donkin, 2008). Crude glycerin is being studied as feed for ruminants (Lage et al., 2010; Van Cleef et al., 2014; Lage et al., 2014) and non-ruminants (Lammers et al., 2008; Mendoza et al., 2010). Glycerol,

Received: January 31, 2017

Accepted: October 2, 2017

*Corresponding author: fredson.silva@unimontes.br

Copyright (C 2018 Sociedade Brasileira de Zootecnia. This is an Open Access article distributed under the terms of the Creative Commons Attribution License (http://creativecommons.org/licenses/by/4.0/), which permits unrestricted use, distribution, and reproduction in any medium, provided the original work is properly cited. the main constituent of glycerin, is an energy source for animals (Duttlinger et al., 2012).

Crude glycerin can be given at a concentration of approximately $100 \mathrm{~g} \mathrm{~kg}^{-1}$ glycerin in the diet dry matter (DM) without affecting performance (Pellegrin et al., 2012; Meale et al., 2013) or carcass and meat characteristics of ruminants (Ramos and Kerley, 2012; San Vito et al., 2015). However, some studies recommend feeding lower amounts of glycerin due to decreased nutrient intake (Parsons et al., 2009; Lage et al., 2010), which results in concerns regarding the use of this ingredient in feedlot diets. No studies have been found in which crude glycerin was given in solution with water, which may produce different results.

In addition to feedlot, the short-term effects of feeding glycerin during pre-slaughter lairage can cause changes in both responses to stress and muscle metabolism (Kannan et al., 2003) and may result in undesirable effects on animal carcass and meat. Concurrently, care taken during pre-slaughter practices (Grandin, 2010) and the provision of easily assimilated feed prior to slaughter may result in better meat quality (Lawrie, 2005).

The hypothesis was that crude glycerin added to water can be used as an ingredient in lamb diets because it improves performance and carcass and meat characteristics. 
The objective of this study was to evaluate performance and carcass and meat characteristics of lambs fed a solution of crude glycerin plus water $\left(100 \mathrm{~g} \mathrm{~kg}^{-1}\right.$ of dry matter) (GLY) during feedlot and pre-slaughter lairage.

\section{Material and Methods}

The procedures performed in this experiment were approved by the local Ethics Committee on Animal Experimentation under the registration CETEA 185/2011.

The experiment was conducted in Igarapé, Minas

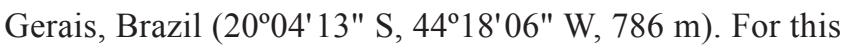
experiment, 24 intact $1 / 2$ Dorper $\times$ Santa Inês male lambs, with an average initial weight of $26.13 \pm 0.48 \mathrm{~kg}$ and an average age of 90 days, were used. In the feedlot, lambs were randomly distributed into two groups: animals that received solution of crude glycerin plus water (GLY) $(n=12)$ and animals that did not receive GLY (Control) $(\mathrm{n}=12)$. At the slaughterhouse, lambs were divided into animals receiving GLY and animals receiving water. Crude glycerin was given in a water solution in both the feedlot and the slaughterhouse. Data were analyzed as a $2 \times 2$ factorial (GLY available or not in feedlot and GLY available or not in the slaughterhouse) with six replicates. The evaluated treatments (feedlot/slaughterhouse) were: GLY/GLY, GLY/water, water/GLY, water/water (control).

Lambs were given a balanced diet for 70 days in the feedlot (Tables 1 and 2). The animals were supplied with the protein and metabolizable energy requirements necessary for a gain of $200 \mathrm{~g} \mathrm{~d}^{-1}$ during the feedlot.

To determine the proportion of GLY in the diet, intake and digestibility of nutrients, testing was previously

Table 1 - Compositions of the experimental diets $\left(\mathrm{g} \mathrm{kg}^{-1}\right.$ of dry matter)

\begin{tabular}{lcc}
\hline & \multicolumn{2}{c}{ Diet } \\
\cline { 2 - 3 } Item & Control & Glycerin \\
\hline Ingredient & & \\
Tifton hay 85 & 415.90 & 409.70 \\
Corn meal & 254.70 & 125.00 \\
Extruded soybean & 275.40 & 311.60 \\
Crude glycerin & - & 100.00 \\
Megalac & 21.80 & 20.70 \\
Urea + ammonium sulfate & 3.00 & 3.00 \\
Mineral salt & 25.00 & 25.00 \\
Dicalcium phosphate & 4.20 & 5.00 \\
Chemical composition & & \\
Dry matter & 741.50 & 752.40 \\
Crude protein & 185.00 & 185.00 \\
Metabolizable energy $\left(\mathrm{kcal} \mathrm{kg}^{-1}\right)$ & 2740 & 2740 \\
Neutral detergent fiber & 367.40 & 350.00 \\
Ca & 6.40 & 6.40 \\
P & 4.10 & 4.10 \\
\hline
\end{tabular}

performed with different levels of this ingredient in solution (Martins, 2013). In this experiment, a $100 \mathrm{~g} \mathrm{~kg}^{-1}$ inclusion of crude glycerin was determined to yield the best results. The crude glycerin was provided by the biodiesel plant of the Archer Daniels Midland Company (AMD) (Rondonopólis, MT, Brazil) and was obtained from soybean oil.

The period of confinement in the feedlot included 14 days for the adaptation of animals to experimental diets and facilities. Lambs were housed in individual stalls of $1.5 \times 3.00 \mathrm{~m}$ in size, with wood shavings for bedding. Animals were weighed at the beginning and end of the adaptation period and every 14 days during the experimental period, after fasting for solids for $16 \mathrm{~h}$. Based on the animal weight, the daily weight gain was estimated, and at the end of the experiment, the feed conversion was calculated. The diets were supplied daily at 7:00 and 16:00 $\mathrm{h}$ in excess by $10 \%$ to ensure leftovers. Depending on the weight range and voluntary intake, feed amounts were adjusted to the requirements of the animals.

Half of the lambs received $7 \mathrm{~kg}$ of water each; this value was estimated so that the animals did not lack water during the day. For the other half, the desired percentage of crude glycerin was placed in a plastic bucket and water was added until a mass of $8 \mathrm{~kg}$ was reached. This procedure was performed at 7:00 $\mathrm{h}$ for each animal. Animals that consumed GLY received their crude glycerin percentage plus $20 \%$ extra. Water and GLY were individually provided in plastic buckets.

The feed supplied and the leftovers were weighed daily for each treatment. To determine intake of crude glycerin, the mixture of this ingredient and water was considered homogenous. Samples of the feed, leftovers, and ingredients were taken weekly. Determinations of the nutrients in the feed were performed according to the procedures described by Horwitz (2000). Neutral detergent fiber was determined following the recommendations of Van Soest et al. (1991).

Table 2 - Analysis of the concentrate, Tifton 85 hay, and crude glycerin ( $\mathrm{g} \mathrm{kg}^{-1}$ of dry matter)

\begin{tabular}{|c|c|c|c|c|}
\hline Item & $\begin{array}{c}\text { Control } \\
\text { concentrate }\end{array}$ & $\begin{array}{c}\text { Glycerin } \\
\text { concentrate }\end{array}$ & Hay & $\begin{array}{l}\text { Crude } \\
\text { glycerin }\end{array}$ \\
\hline \multicolumn{5}{|l|}{ Chemical composition } \\
\hline Dry matter & 717.40 & 716.90 & 770.00 & 854.00 \\
\hline Crude protein & 280.06 & 311.00 & 79.80 & 0.60 \\
\hline Ether extract & 57.75 & 57.74 & 50.00 & 134.10 \\
\hline Minerals & 93.94 & 99.88 & 59.60 & 57.10 \\
\hline Neutral detergent fiber & 131.77 & 131.02 & 590.10 & - \\
\hline Glycerol & - & - & - & 807.00 \\
\hline Methanol & - & - & - & 0.20 \\
\hline Density $\left(\mathrm{g} \mathrm{mL}^{-1}\right)$ & & & & 1.20 \\
\hline Gross energy $\left(\mathrm{kcal} \mathrm{kg}^{-1}\right)$ & - & - & - & 2344.90 \\
\hline
\end{tabular}


The glycerol and methanol contents of the crude glycerin were obtained using gas chromatography.

At the end of the feedlot, lambs were sent to the slaughterhouse, where the second phase of this experiment was conducted. There were no stops during the journey and lambs did not have access to water or feed during the transfer. The travelled distance was $160 \mathrm{~km}$, six of which were travelled on unpaved roads. The loading, transportation, and unloading were conducted following the recommendations of Paranhos da Costa et al. (2010, 2011).

After unloaded, sheep were placed into four collective pens according to the previously described treatments. Each collective pen was subdivided by means of iron grids, each with plastic buckets. The methodology used to supply GLY and water was the same as in the feedlot.

Slaughter commenced $12 \mathrm{~h}$ after the animals arrived at the slaughterhouse. The animals were stunned with an electro narcosis system, consisting of two electrodes placed on the head of the animal, which was immediately followed by bleeding, in accordance with the Brazilian Federal Meat Inspection Regulations (Brasil, 1997).

Approximately 45 min after bleeding, the $\mathrm{pH}(\mathrm{pHi})$ was measured in the loin (LM thoracic set lumborum), as described by Pearce et al. (2010), using a portable $\mathrm{pH}$ meter. The forestomaches, stomachs, and intestines were weighed full; after washing, they were also weighed empty. The hot carcasses were weighed, washed, and taken to a cooling chamber with temperature ranging from 2 to $4{ }^{\circ} \mathrm{C}$ for $24 \mathrm{~h}$. After cooling, the carcasses were weighed again and the $\mathrm{pH}$ was measured $(\mathrm{pHu})$. In the cold carcasses, using a measuring tape, measurements of the internal lengths and perimeters of the thorax and legs were taken, according to Sañudo and Sierra (1986). Subcutaneous fat thickness and ribeye area were evaluated using the United States Standards for Grades of Carcass Beef (1997), as described by Gomide et al. (2006).

A $10-\mathrm{cm}$ section of deboned longissimus muscle was removed from the carcass after $24 \mathrm{~h}$ of cooling. This muscle was then vacuum packed and subjected to analysis. Meat color, water loss by cooking, water holding capacity, water activity, and shear force were assessed on this portion of the loin.

Values of $\mathrm{L}^{*}, \mathrm{a}^{*}$, and $\mathrm{b}^{*}$ were measured according to the description of Devine et al. (2002) using the Hunter lab Miniscan EZ.

To determine water loss by cooking, meat was weighed $(68.00 \pm 1.78 \mathrm{~g})$ and placed on an electric grill. Cooking was performed with cuts of the loin wrapped in aluminum foil. When the temperature at the coldest point of the steaks reached $40{ }^{\circ} \mathrm{C}$, they were turned over, and the other side was grilled until it reached $71{ }^{\circ} \mathrm{C}$. The sections of meat were then cooled to room temperature and weighed again (Ramos and Gomide, 2007).

Cylindrical samples were then taken from the meat sections that underwent cooking. These samples had a diameter of $1.27 \mathrm{~cm}$ and were used to perform the objective analysis of shear force, which was measured using a Warner-Bratzler device (Wheeler et al., 2001).

The part of the raw longissimus muscle that remained after the steaks were taken for cooking was used to evaluate the water holding capacity. These samples were subjected to centrifugation (1500 rpm for $4 \mathrm{~min}$ ) and placed in an oven $\left(70{ }^{\circ} \mathrm{C}\right.$ for $18 \mathrm{~h}$ ). The water holding capacity was calculated by the difference in weight (Nakamura and Katoh, 1981). Other raw samples were used to measure water activity by means of the Aqualab ${ }^{\circledR}$ series 3 TE instrument.

The experimental design was completely randomized and each animal represented a experimental unit. The dependent variables dry matter intake (DMI), water intake, feed conversion, daily weight gain, and final body weight were only assessed while the animals were in the feedlot ( $\mathrm{T}$ test; $\mathrm{P}<0.05$ ). The other data were subjected to analysis of variance and their mean values were compared by the Student-Newman-Keuls test $(\mathrm{P}<0.05)$, when significant. The interactions between the independent variables (feedlot - control diet or diet with GLY; slaughterhouse - water or GLY) and the dependent variables were tested. Adjustment of the dependent variables was performed by analyzing the covariable initial body weight, when significant $(\mathrm{P}<0.05)$. For the variable intake of GLY or water, which was determined in the slaughterhouse, the assumptions of normality for the residue and homogeneity of variances were not met; therefore, a Kruskal-Wallis test was performed $(\mathrm{P}<0.05)$.

The mathematical model used was:

$$
\mathrm{y}_{\mathrm{ijk}}=\mu+\alpha_{\mathrm{i}}+\beta_{\mathrm{j}}+\alpha_{\mathrm{i}} \beta_{\mathrm{j}}+\mathrm{e}_{\mathrm{ijk}},
$$

in which $\mathrm{y}_{\mathrm{ijk}}=$ observed value of the variable that received glycerin in feedlot $i$, that received glycerin in slaughterhouse $\mathrm{j}$, and repetition $\mathrm{k} ; \mu=$ overall mean; $\alpha_{\mathrm{i}}=$ feedlot - control diet or diet with GLY; $\beta_{\mathrm{j}}=$ slaughterhouse - water or GLY; $\alpha_{\mathrm{i}} \beta_{\mathrm{j}}=$ effect of interaction; and $\mathrm{e}_{\mathrm{ijk}}=$ random error associated with each observation.

\section{Results}

The values of DMI, feed conversion, daily weight gain, and final body weight of lambs were similar between the animals receiving GLY and the control animals (Table 3). The lambs receiving GLY ingested more water in the feedlot. 
At the slaughterhouse, water/GLY animals consumed more crude glycerin than GLY/water consumed water. The other contrasts were similar (Table 4).

Among all analyzed variables, there was interaction only for drip loss (Table 5). Group GLY/GLY had lower drip loss in carcasses than the group GLY/water. The other carcass characteristics and weights of forestomaches, stomachs, and intestines were similar among treatments.

Table 3 - Performance of lambs finished on diets with or without crude glycerin

\begin{tabular}{lccrr}
\hline & \multicolumn{2}{c}{ Treatment $^{1}$} & & \\
\cline { 2 - 3 } Item & Control & $\begin{array}{c}\text { Crude } \\
\text { glycerin }\end{array}$ & SEM & P-value \\
\hline Dry matter intake $\left(\mathrm{kg} \mathrm{day}^{-1}\right)$ & 0.78 & 0.76 & 0.03 & 0.738 \\
Water intake $^{2}\left(\mathrm{~kg} \mathrm{day}^{-1}\right)$ & 3.35 & 4.10 & 0.22 & 0.022 \\
${\text { Feed conversion }\left(\mathrm{weight} \mathrm{weight}^{-1}\right)}$ & 3.47 & 3.60 & 0.10 & 0.384 \\
Average daily gain $\left(\mathrm{g} \mathrm{day}^{-1}\right)$ & 227.90 & 214.90 & 8.50 & 0.315 \\
Final body weight $(\mathrm{kg})$ & 37.82 & 37.20 & 0.60 & 0.557 \\
\hline
\end{tabular}

${ }^{1}$ Control: no crude glycerin; Crude glycerin: $100 \mathrm{~g} \mathrm{~kg}^{-1}$ of dry matter.

${ }^{2}$ Water of the feed not taken in consideration.

SEM - standard error of the mean.

Table 4 - Intake of the solution of crude glycerin and water or water and intake of crude glycerin in the slaughterhouse

\begin{tabular}{|c|c|c|c|c|}
\hline Treatment $^{1}$ & $\begin{array}{l}\text { GLY or water } \\
\left.(\mathrm{kg} \mathrm{lamb})^{-1}\right)^{2}\end{array}$ & $\begin{array}{l}25 \text { th and } 75 \text { th } \\
\text { percentiles }\end{array}$ & $\begin{array}{l}\text { Crude glycerin } \\
\left(\mathrm{g} \mathrm{DM} \mathrm{lamb}^{-1}\right)\end{array}$ & $\begin{array}{l}25 \text { th and } 75 \text { th } \\
\text { percentiles }\end{array}$ \\
\hline GLY/GLY & $2.15 \mathrm{ab}$ & $1.47-2.84$ & 26.74 & $18.28-35.32$ \\
\hline GLY/water & $1.06 \mathrm{~b}$ & $0.75-1.37$ & - & - \\
\hline Water/GLY & $2.70 \mathrm{a}$ & $2.11-3.30$ & 33.58 & 26.24-41.04 \\
\hline Water/water & $1.16 \mathrm{ab}$ & $0.41-1.92$ & - & - \\
\hline
\end{tabular}

GLY: solution of crude glycerin and water.

${ }^{1}$ Treatments (Feedlot/pre-slaughter).

${ }^{2}$ Medians within a column with different uppercase letters differ by the Kruskal-

Wallis test $(\mathrm{P}=0.008)$
Meat characteristics were similar among treatments (Table 6).

\section{Discussion}

Agreeing with this study, Gomes et al. (2011) found no differences in DMI, feed conversion, daily weight gain, and final body weight with the inclusion of crude glycerin (300 $\mathrm{g} \mathrm{kg}^{-1}$ of diet DM) to the diet for lambs. Lage et al. (2010), Avila-Stagno et al. (2013), and Barros et al. (2015) indicated the use of smaller proportions of crude glycerin than that used in the present experiment due to decreased DMI. The administration of the feed in this experiment, crude glycerin conveyed to water, may have determined maintenance of DMI and performance, since there is a slower intake of glucose and propionate, an important hypothalamic informant of the degree of satiety (Allen, 2000).

In contrast to this study, Avila-Stagno et al. (2013) showed that the trend to reduced daily weight gain with increasing concentrations of glycerol in diets is likely due to reduction in DMI. No effect of addition of crude glycerin in lamb diets on daily weight gain was reported in the study of Gunn et al. (2010).

Mixture of glycerol and propylene glycol (35 and $15 \mathrm{~g} \mathrm{~kg}^{-1}$, respectively) usually doubles the water intake of lambs or cattle over a 1-2-day period (Pethick et al., 2000), which results in hyperhydration (Parker et al., 2007) and advantages in pre-slaughter.

Parker et al. (2007), evaluating metabolic effects of prophylactic treatment with the osmolyte glycerol on Bos indicus steers, claimed that glycerol increased water

Table 5 - Carcass characteristics of lambs fed a solution of crude glycerin during feedlot and pre-slaughter lairage

\begin{tabular}{|c|c|c|c|c|c|c|c|c|}
\hline \multirow{2}{*}{ Item } & \multicolumn{2}{|c|}{ Feedlot $(F)$} & \multicolumn{2}{|c|}{ Pre-slaughter (PS) } & \multirow{2}{*}{ SEM } & \multicolumn{3}{|c|}{ P-value } \\
\hline & GLY & Control & GLY & Control & & $\mathrm{F}$ & PS & $\mathrm{F} \times \mathrm{PS}$ \\
\hline \multicolumn{9}{|l|}{ Carcass characteristic } \\
\hline Initial pH & 6.81 & 6.71 & 6.69 & 6.82 & 0.06 & 0.132 & 0.055 & 0.202 \\
\hline Hot cacass weight $(\mathrm{kg})$ & 16.65 & 17.35 & 16.82 & 17.18 & 0.58 & 0.270 & 0.571 & 0.331 \\
\hline Ultimate $\mathrm{pH}$ & 6.05 & 5.99 & 5.99 & 6.05 & 0.08 & 0.241 & 0.241 & 0.444 \\
\hline Cold carcass weight $(\mathrm{kg})$ & 16.04 & 16.78 & 16.29 & 16.52 & 0.56 & 0.227 & 0.703 & 0.427 \\
\hline Drip $\operatorname{loss}^{1}(\mathrm{~g} / 100 \mathrm{~g})$ & $2.99 \mathrm{a}$ & $4.63 b$ & $3.57 \mathrm{ab}$ & $3.21 \mathrm{ab}$ & 0.38 & 0.169 & 0.101 & 0.034 \\
\hline \multicolumn{9}{|l|}{ Carcass measurement } \\
\hline Subcutaneous fat thickness (mm) & 2.04 & 2.15 & 2.08 & 2.11 & 0.26 & 0.690 & 0.909 & 0.094 \\
\hline Total length $(\mathrm{cm})$ & 54.80 & 55.32 & 54.73 & 55.39 & 0.91 & 0.607 & 0.512 & 0.993 \\
\hline Perimeter of thorax $(\mathrm{cm})$ & 77.43 & 78.13 & 76.63 & 78.93 & 1.46 & 0.642 & 0.144 & 0.377 \\
\hline Perimeter of leg $(\mathrm{cm})$ & 46.10 & 44.58 & 44.70 & 46.00 & 1.57 & 0.369 & 0.434 & 0.153 \\
\hline Ribeye area ( $\mathrm{cm}^{2} / \mathrm{kg}$ of body weight) & 0.31 & 0.32 & 0.31 & 0.32 & 0.03 & 0.924 & 0.654 & 0.689 \\
\hline \multicolumn{9}{|l|}{ Forestomaches, stomachs, and intestines } \\
\hline Full stomach $(\mathrm{kg})$ & 6.28 & 6.09 & 6.25 & 6.12 & 0.27 & 0.554 & 0.648 & 0.652 \\
\hline Empty stomach (kg) & 1.23 & 1.26 & 1.22 & 1.27 & 0.05 & 0.599 & 0.346 & 0.583 \\
\hline Full intestines $(\mathrm{kg})$ & 2.59 & 2.61 & 2.62 & 2.58 & 0.07 & 0.993 & 0.380 & 0.104 \\
\hline Empty intestines $(\mathrm{kg})$ & 1.28 & 1.36 & 1.33 & 1.31 & 0.04 & 0.119 & 0.664 & 0.076 \\
\hline
\end{tabular}

GLY: solution of crude glycerin and water; Control: no crude glycerin.

${ }^{1}$ Treatments (feedlot/slaughterhouse): GLY/GLY, GLY/water, water/GLY, and control (water/water), respectively.

Means in the same row with different letters differ according to SNK test $(\mathrm{P}<0.05)$. 
Table 6 - Meat characteristics of lambs fed a solution of crude glycerin during feedlot and pre-slaughter lairage

\begin{tabular}{|c|c|c|c|c|c|c|c|c|}
\hline \multirow{2}{*}{ Item } & \multicolumn{2}{|c|}{ Feedlot (F) } & \multicolumn{2}{|c|}{ Pre-slaughter (PS) } & \multirow{2}{*}{ SEM } & \multicolumn{3}{|c|}{ P-value } \\
\hline & GLY & Control & GLY & Control & & $\mathrm{F}$ & PS & $\mathrm{F} \times \mathrm{PS}$ \\
\hline Ultimate $\mathrm{pH}$ & 6.05 & 5.99 & 5.99 & 6.05 & 0.08 & 0.241 & 0.241 & 0.444 \\
\hline Hunter $L^{*}$ & 33.53 & 34.37 & 34.56 & 33.34 & 1.19 & 0.523 & 0.363 & 0.873 \\
\hline Hunter b* & 11.53 & 11.79 & 11.47 & 11.85 & 0.61 & 0.697 & 0.577 & 0.817 \\
\hline WHC (g/100 g) & 61.60 & 62.14 & 61.53 & 62.21 & 2.47 & 0.841 & 0.803 & 0.952 \\
\hline Water activity & 0.99 & 0.99 & 0.99 & 0.99 & 0.00 & 1.000 & 0.555 & 0.555 \\
\hline
\end{tabular}

GLY: solution of crude glycerin and water; Control: no crude glycerin.

WHC - water holding capacity; CL - cooking losses; SF - shear force; SEM - standard error of the mean.

retention in the body. Therefore, the increased water intake of animals that consumed GLY during feedlot did not result in a consistent response for drip loss.

Carvalho et al. (2015) reported that hot carcass weight and cold carcass weight decreased with increasing dietary crude glycerin (up to $300 \mathrm{~g} \mathrm{~kg}^{-1}$ crude glycerin; DM basis) and subcutaneous fat thickness and the ribeye area were not affected. The similarities between most of the quantitative carcass characteristics in this experiment and those characteristics involving measurements were reflected in the similarities of treatments in terms of DMI and performance in the feedlot, as reported by Van Cleef et al. (2014) with diets containing crude glycerin. AvilaStagno et al. (2013) reported that the increase of glycerol in the diet descreased DMI, but hot carcass weight was not affected.

Similar to the present study, Borghi et al. (2016) found no changes in water holding capacity, cooking losses, and shear force in meat of lambs fed diets containing different levels of crude glycerin. Likewise, Lage et al. (2014) did not find changes in ultimate $\mathrm{pH}$, cooking losses, and shear force in meat of lambs fed diets containing different levels of crude glycerin. The mean values for shear force, in all treatments, were below those considered by Souza et al. (2004) as the upper limit for considering the meat as tender.

Glycerol increases fluid retention by means of the reduction of free water in the organism (Freund et al., 1995). However, the water activity of this study was not affected.

Color variables remained within previously reported normal ranges of 30.03 to 49.47 for $\mathrm{L}^{*}, 8.24$ to 23.53 for $\mathrm{a}^{*}$, and 3.30 to 11.10 for $\mathrm{b}^{*}$ (Sañudo et al., 2008). Carvalho et al. (2014) reported increases in $\mathrm{L}^{*}$ and $\mathrm{b}^{*}$ for cow meat and justified these findings by the increase in fat in the longissimus muscle, an increase which did not occur in the present experiment.

\section{Conclusions}

Solution of crude glycerin plus water can be used as a dietary ingredient for lambs, since it improves hydration and does not change performance and carcass characteristics. This solution supplied as a pre-slaughter supplement does not improve carcass and meat characteristics.

\section{Acknowledgments}

The authors thank the Conselho Nacional de Desenvolvimento Científico e Tecnológico (CNPq), for the financing of the project, and the $\mathrm{CNPq}$, the Coordenação de Aperfeiçoamento de Pessoal de Nível Superior (CAPES), and the Fundação de Amparo à Pesquisa do Estado de Minas Gerais (FAPEMIG), for the scholarships and research grants granted to the authors.

\section{References}

Allen, M. S. 2000. Effects of diet on short-term regulation of feed intake by lactating dairy cattle. Journal of Dairy Science 83:1598-1624. doi: $10.3168 /$ jds.S0022-0302(00)75030-2.

Avila-Stagno, J.; Chaves, A. V.; He, M. L.; Harstad, O. M.; Beauchemin, K. A.; McGinn, S. M. and McAllister, T. A. 2013. Effects of increasing concentrations of glycerol in concentrate diets on nutrient digestibility, methane emissions, growth, fatty acid profiles, and carcass traits of lambs. Journal of Animal Science 91:829-837. doi: 10.2527/jas.2012-5215.

Barros, M. C. C.; Araújo Marques, J.; Silva, F. F.; Silva, R. R.; Guimarães, G. S.; Silva, L. L. and Araújo, F. L. 2015. Glicerina bruta na dieta de ovinos confinados: consumo, digestibilidade, desempenho, medidas morfométricas da carcaça e características da carne. Semina: Ciências Agrárias 36:453-466.

Borghi, T. H.; Silva Sobrinho; A. G. D.; Zeola, N. M. B. L.; Almeida, F. A. D.; Cirne, L. G. A. and Lima, A. R. C. 2016. Dietary glycerin does not affect meat quality of Ile de France lambs. Revista Brasileira de Zootecnia 45:554-562. doi: 10.1590/s1806-92902016000900008.

Brasil. 2014. Lei $n^{\circ} 13.033$, de 24 de setembro de 2014. Dispõe sobre a adição obrigatória de biodiesel ao óleo diesel comercializado com o consumidor final. Diário Oficial da União, Brasília, DF, 25 set. 2014. Seção 1. 
Brasil. 1997. Ministério da Agricultura e do Abastecimento. Departamento de Inspeção de Produtos de Origem Animal. Divisão de Normas Técnicas. Regulamento da inspeção industrial e sanitária de produtos de origem animal: aprovado pelo Decreto $\mathrm{n}^{\circ} 30.691$, de 29-03-52, alterado pelos Decretos $\mathrm{n}^{\circ} 1.255$ de 25-06-62, $\mathrm{n}^{\circ} 1.236$ de 02-09-94, $\mathrm{n}^{\circ} 1.812$ de 08-02-96 e n $\mathrm{n}^{\circ} 2.244$ de 04-06-97. Ministério da Agricultura, Brasília, DF.

Carvalho, J. R. R.; Chizzotti, M. L.; Ramos, E. M.; Machado Neto, O. R.; Lanna, D. P. D.; Lopes, L. S.; Teixeira, P. D. and Ladeira, M. M. 2014. Qualitative characteristics of meat from young bulls fed different levels of crude glycerin. Meat Science 96:977-983. doi: 10.1016/j.meatsci.2013.10.020.

Carvalho, V. B.; Leite, R. F.; Almeida, M. T. C.; Paschoaloto, J. R.; Carvalho, E. B.; Lanna, D. P. D.; Van Cleef, E. H. C. B.; Homem Junior, A. C. and Ezequiel, J. M. B. 2015. Carcass characteristics and meat quality of lambs fed high concentrations of crude glycerin in low-starch diets. Meat Science 110:285-292. doi: 10.1016/j.meatsci.2015.08.001.

Devine, C. E.; Payne, S. R.; Peachey, B. M.; Lowe, T. E.; Ingram, J. R. and Cook, C. J. 2002. High and low rigor temperature effects on sheep meat tenderness and ageing. Meat Science 60:141-146. doi: 10.1016/S0309-1740(01)00115-2.

Donkin, S. S. 2008. Glycerol from biodiesel production: the new corn for dairy cattle. Revista Brasileira de Zootecnia 37:280-286. doi: 10.1590/S1516-35982008001300032.

Duttlinger, A. J.; DeRouchey, J. M.; Tokach, M. D.; Dritz, S. S.; Goodband, R. D.; Nelssen, J. L.; Houser, T. A. and Sulabo, R. C. 2012. Effects of increasing crude glycerol and dried distillers grains with solubles on growth performance, carcass characteristics, and carcass fat quality of finishing pigs. Journal of Animal Science 90:840-852. doi: 10.2527/jas.2011-4126.

Freund, B. J.; Montain, S. J.; Young, A. J.; Sawka, M. N.; DeLuca, J. P.; Pandolf, K. B. and Valeri, C. R. 1995. Glycerol hyperhydration: Hormonal, renal, and vascular fluid responses. Journal of Applied Physiology 79:2069-2077.

Gomide, L. D. M.; Ramos, E. M. and Fontes, P. R. 2006. Tecnologia de abate e tipificação de carcaças. UFV, Viçosa, MG, Brasil.

Gomes, M. A. B.; Moraes, G. V. D.; Mataveli, M.; Macedo, F. D. A. F. D.; Carneiro, T. C. and Rossi, R. M. 2011. Performance and carcass characteristics of lambs fed on diets supplemented with glycerin from biodiesel production. Revista Brasileira de Zootecnia 40:22112219. doi: 10.1590/S1516-35982011001000022.

Grandin, T. 2010. Auditing animal welfare at slaughter plants. Meat Science 86:56-65. doi: 10.1016/j.meatsci.2010.04.022.

Gunn, P. J.; Neary, M. K.; Lemenager, R. P. and Lake, S. L. 2010. Effects of crude glycerin on performance and carcass characteristics of finishing wether lambs. Journal of Animal Science 88:17711776. doi: $10.2527 /$ jas.2009-2325.

Horwitz, W. 2000. Official methods of analysis of AOAC International. AOAC International, Gaithersburg.

Kannan, G.; Kouakou, B.; Terrill, T. H. and Gelaye, S. 2003. Endocrine, blood metabolite, and meat quality changes in goats as influenced by short-term, preslaughter stress. Journal of Animal Science 81:1499-1507.

Lage, J. F.; Paulino, P. V. R.; Pereira, L. G. R.; Duarte, M. S.; Valadares Filho, S. C.; Oliveira, A. S.; Souza, N. K. P. and Lima, J. C. M. 2014. Carcass characteristics of feedlot lambs fed crude glycerin contaminated with high concentrations of crude fat. Meat Science 96:108-113. doi: 10.1016/j.meatsci.2013.06.020.

Lage, J. F.; Paulino, P. V. R.; Pereira, L. G. R.; Valadares Filho, S. D. C.; Oliveira, A. S. D.; Detmann, E.; Souza, N. K. P. and Lima, J. C. M. 2010. Glicerina bruta na dieta de cordeiros terminados em confinamento. Pesquisa Agropecuária Brasileira 45:1012-1020. doi: 10.1590/S0100-204X2010000900011.

Lammers, P. J.; Kerr, B. J.; Weber, T. E.; Bregendahl, K.; Lonergan, S. M.; Prusa, K. J.; Ahn, D. U.; Stoffregen, W. C.; Dozier III, W.
A. and Honeyman, M. S. 2008. Growth performance, carcass characteristics, meat quality, and tissue histology of growing pigs fed crude glycerin-supplemented diets. Journal of Animal Science 86:2962-2970. doi: 10.2527/jas.2008-0972.

Lawrie, R. A. 2005. Ciência da carne. Artmed, Porto Alegre.

Martins, T. L. T. 2013. Soro de leite e glicerina veiculados à água para borregos. Dissertação (M. Sc.). Universidade Federal de Minas Gerais, Belo Horizonte.

Meale, S. J.; Chaves, A. V.; Ding, S.; Bush, R. D. and McAllister, T. A. 2013. Effects of crude glycerin supplementation on wool production, feeding behavior, and body condition of Merino ewes. Journal of Animal Science 91:878-885. doi: 10.2527/jas.2012-5791.

Mendoza, O. F.; Ellis, M.; McKeith, F. K. and Gaines, A. M. 2010. Metabolizable energy content of refined glycerin and its effects on growth performance and carcass and pork quality characteristics of finishing pigs. Journal of Animal Science 88:3887-3895. doi: 10.2527/jas.2010-2873.

Nakamura, M. and Katoh, K. 1981. Influence of thawing methods on several properties of rabbit meat. Bulletin of Ishikawa Prefecture College of Agriculture 11:45-49.

Paranhos da Costa, M. J. R.; Quintiliano, M. H. and Tseimazides, S. P. 2011. Boas práticas de manejo: transporte. FUNEP, Jaboticabal.

Paranhos da Costa, M. J. R. Spironelli, A. L. G. and Quintiliano, M. H. 2010. Boas práticas de manejo: embarque. FUNEP, Jaboticabal.

Parker, A. J.; Dobson, G. P. and Fitzpatrick, L. A. 2007. Physiological and metabolic effects of prophylactic treatment with the osmolytes glycerol and betaine on Bos indicus steers during long duration transportation. Journal of Animal Science 85:2916-2923. doi: 10.2527/jas.2006-193.

Parsons, G. L.; Shelor, M. K. and Drouillard, J. S. 2009. Performance and carcass traits of finishing heifers fed crude glycerin. Journal of Animal Science 87:653-657. doi: 10.2527/jas.2008-1053.

Pearce, K. L.; Van De Ven, R.; Mudford, C.; Warner, R. D.; HockingEdwards, J.; Jacob, R.; Pethick, D. W. and Hopkins, D. L. 2010. Case studies demonstrating the benefits on $\mathrm{pH}$ and temperature decline of optimizing medium-voltage electrical stimulation of lamb carcasses. Animal Production Science 50:1107-1114. doi: 10.1071/AN10114.

Pellegrin, A. C. R. S.; Pires, C. C.; Carvalho, S.; Pacheco, P. S.; Pelegrini, L. F. V.; Griebler, L. and Venturini, R. S. 2012. Glicerina bruta no suplemento para cordeiros lactentes em pastejo de azevém. Ciência Rural 42:1477-1482.

Pethick, D. W.; Cummins, L.; Gardner, G. E.; Jacob, R. H.; Knee, B. W.; McDowell, M.; McIntyre, B. L.; Tudor, G.; Walker, P. J. and Warner, W. D. 2000. The regulation of glycogen level in the muscle of ruminants by nutrition. Proceedings of the New Zealand Society of Animal Production 60:94-98.

Ramos, E. M. and Gomide, L. A. 2007. Avaliação da qualidade de carnes: fundamentos e metodologias. UFV, Viçosa, MG, Brazil.

Ramos, M. H. and Kerley, M. S. 2012. Effect of dietary crude glycerol level on ruminal fermentation in continuous culture and growth performance of beef calves. Journal of Animal Science 90:892-899. doi: 10.2527/jas.2011-4099.

San Vito, E.; Lage, J. F.; Ribeiro, A. F.; Silva, R. A. and Berchielli, T. T. 2015. Fatty acid profile, carcass and quality traits of meat from Nellore young bulls on pasture supplemented with crude glycerin. Meat Science 100:17-23. doi: 10.1016/j.meatsci.2014.09.008.

Sañudo, C.; Arribas, M. D. M. C. and Silva Sobrinho, A. G. 2008. Qualidade da carcaça da carne ovina e seus fatores determinantes. p.177-228. In: Produção de carne ovina. Silva Sobrinho, A. G., ed. FUNEP, Jaboticabal.

Sañudo, C. and Sierra, I. 1986. Calidad de la canal en la especie ovina. p.127-153. In: Ovino. One S.A., Barcelona.

Souza, X. R.; Bressan, M. C.; Pérez, J. R. O.; Faria, P. B.; Vieira, J. O. and Kabeya, D. M. 2004. Efeitos do grupo genético, sexo e peso ao 
abate sobre as propriedades físico-químicas da carne de cordeiros em crescimento. Ciência e Tecnologia de Alimentos 24:543-549. doi: 10.1590/S0101-20612004000400011.

Van Cleef, E. H. C. B.; Ezequiel, J. M. B.; D’Aurea, A. P.; Fávaro, V. R. and Sancanari, J. B. D. 2014. Crude glycerin in diets for feedlot Nellore cattle. Revista Brasileira de Zootecnia 43:86-91. doi: 10.1590/S1516-35982014000200006.
Van Soest, P. V.; Robertson, J. B. and Lewis, B. A. 1991. Methods for dietary fiber, neutral detergent fiber, and non-starch polysaccharides in relation to animal nutrition. Journal of Dairy Science 74:3583-3597. doi: 10.3168/jds.S0022-0302(91)78551-2.

Wheeler, T. L.; Shackelford, S. D. and Koohmaraie, M. 2001. Shear force procedures for meat tenderness measurement. Roman L. Hruska US Marc. USDA, Clay Center, NE. 